Article

\title{
Influence of Climate and Land Use Change on the Groundwater System of the Veluwe, The Netherlands: A Historical and Future Perspective
}

\author{
Marjolein H. J. Van Huijgevoort ${ }^{1, * \mathbb{D}}$, Bernard R. Voortman ${ }^{1,2}$, Sjoerd Rijpkema ${ }^{3,+} \mathbb{(}$, \\ Kelly H. S. Nijhuis ${ }^{1, \ddagger}$ and Jan-Philip M. Witte ${ }^{1,4}$ \\ 1 KWR Water Research Institute, 3430BB Nieuwegein, The Netherlands; \\ bernard.voortman@moisture-matters.nl (B.R.V.); kelly3x3@live.nl (K.H.S.N.); \\ flip.witte@ecohydrologie.nl (J.-P.M.W.) \\ 2 Moisture Matters, 3533ED Utrecht, The Netherlands \\ 3 Vitens, 6802CA Arnhem, The Netherlands; S.Rijpkema@waterbedrijfgroningen.nl \\ 4 Flip Witte Ecohydrologie, 6862DC Oosterbeek, The Netherlands \\ * Correspondence: marjolein.van.huijgevoort@kwrwater.nl \\ + Current address: Waterbedrijf Groningen, 9723DV Groningen, The Netherlands. \\ $\ddagger$ Current address: Waterschap Vallei en Veluwe, 7324AX Apeldoorn, The Netherlands.
}

Received: 27 August 2020; Accepted: 4 October 2020; Published: 15 October 2020

check for updates

\begin{abstract}
Changes in land use and climate have a large influence on groundwater recharge and levels. In The Netherlands, precipitation shifts from summer to winter are expected, combined with an increase in summer temperature leading to higher evaporation. These changes in climate could threaten the fresh water supply and increase the importance of large groundwater reservoirs. Sustainable management of these groundwater reservoirs, therefore, is crucial. Changes in land use could help mitigate the effects of climate change by decreasing the evaporation. In this study, we investigate the effect of changes in climate and land use on a large groundwater reservoir in The Netherlands, the Veluwe, for a historical period (1850-2016) and in the future (2036-2065). During the historical period, evaporation increased due to conversions from heather and drift sand to pine forest across the Veluwe. This change in land use had a larger effect on the groundwater recharge than change in climate over the historical period. In the future, an increase in winter precipitation will lead to higher groundwater levels in the elevated parts of the region. Surrounding areas are more vulnerable to an increase in dry periods in the summer. Groundwater reservoirs provide an opportunity to store water during wetter periods, which could alleviate drought impacts in surrounding regions during dry periods. Land use change, such as conversion from pine forest to other land use types, is a possible measure to increase water availability.
\end{abstract}

Keywords: groundwater; land use; climate change; evaporation

\section{Introduction}

Climate change will affect the availability of fresh water resources in the future (e.g., [1,2]) and will, therefore, have consequences for nature (e.g., [3]), agriculture (e.g., [4]), industry (e.g., [5]) and drinking water supply (e.g., [6]). In The Netherlands, precipitation shifts from summer to winter are expected, combined with increased evaporation demands in summer due to higher temperatures [7]. This can lead to longer and more intense dry spells occurring more often across The Netherlands [7]. 
Groundwater recharge and levels are impacted by these changes in climate [8-10], but also by changes in land use [11-14]. Actual evaporation (sum of interception, soil evaporation and transpiration) is partly determined by vegetation type. The vegetation, therefore, plays a critical role in groundwater recharge, where, for example, pine forest has a higher evaporation than heather $[15,16]$. Differences in evaporation between land use types are significant with an actual evaporation of $201 \mathrm{~mm} /$ year for drift sand [17], $430 \mathrm{~mm}$ /year for heather [18] and $630 \mathrm{~mm} /$ year for pine forest [15]. Decisions about land use could thus be important to mitigate climate change effects on groundwater reservoirs.

It is important to consider the impacts of climate change and land use change on strategic groundwater reservoirs, because sustainable management of these groundwater reservoirs is crucial—e.g., in [19]—to ensure freshwater availability for all sectors (e.g., drinking water, nature and agriculture). Groundwater will be affected by climate change, but projected impacts are uncertain [20]. The resilience of groundwater resources to hydrological extremes, compared to other fresh water resources, means that groundwater reservoirs will become even more important in the future [20]. These reservoirs, however, are already being depleted in many regions [21], emphasizing the need for sustainable management.

The Veluwe area is a primary strategic groundwater system in The Netherlands [22] and an important region for drinking water supply [23]. The effects of changes in land use and climate on the water balance of the Veluwe are investigated in this study in a historical and future perspective. The changes that occurred in the past (from 1850 onward) can provide an important lesson for sustainable management of the system in the future.

The aim of this study is to place the hydrological consequences of climate change for the Veluwe in a historical perspective and to compare them with the effects of changes in land use. For this purpose, the effect of climate and land use changes on the groundwater reservoir of the Veluwe are quantified for (i) historical (1850-2016), and (ii) future (2036-2065) conditions. The impact of the changes is simulated with a groundwater model based on historical data and future scenarios.

\section{Site Description}

The Veluwe area (ca. $1250 \mathrm{~km}^{2}$ ) is located in the centre of The Netherlands (Figure 1) and consists of ice-pushed ridges and fluvio-glacial complexes (Figure 2) [22,24,25]. It is an elevated sandy area (Figure 1), which contains a large aquifer of fresh groundwater. On top of the deep aquifer (to $200 \mathrm{~m}$ deep) lies a large unsaturated zone up to $60 \mathrm{~m}$ thick [22,23]. The unsaturated zone consists mainly of sediments of sands [22]. The soils vary from fine sand to coarse sand [22]. In the ice-pushed ridges, tilted and discontinues clay layers exist that have a large impact on the groundwater table creating a spatially discontinuous pattern [22]. Due to the expanse of the area and its large unsaturated zone, the groundwater system responds slowly to changes in meteorological conditions. Brooks and streams are found at the fringe of the sandy area, where water exfiltrates. Upward seepage occurs in surrounding lower lying agricultural areas and seepage dependent nature areas with a species rich, rare and endangered vegetation (especially Junco-Molinion and Calthion grasslands and Circaeo-Alnenion woodlands). No drainage systems exist in the central part of the area. Most of the area is designated nature reserve and land use mainly consists of forests (predominantly pine), heather and drift sand [26]. 

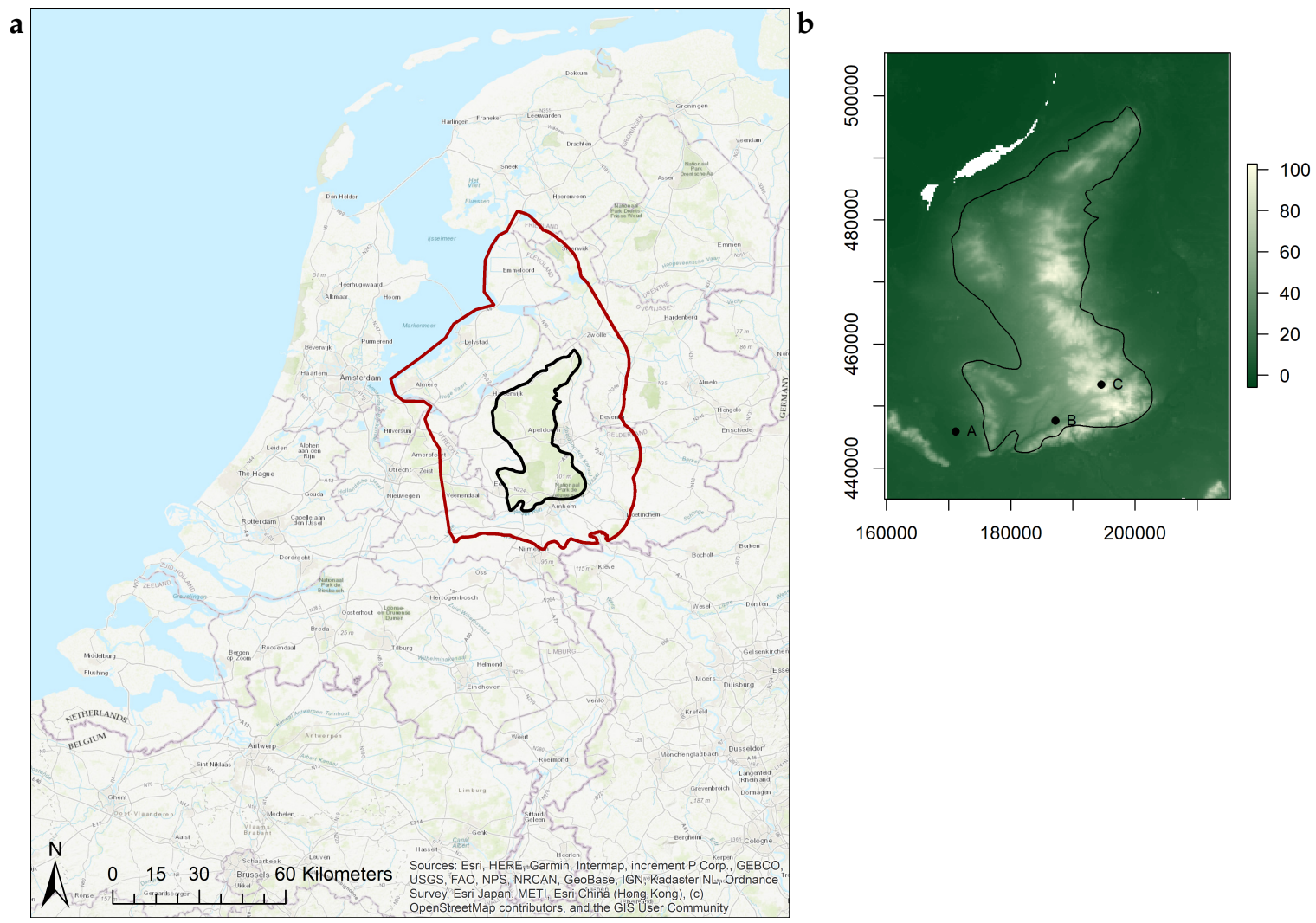

Figure 1. (a) Location of the Veluwe area in The Netherlands. The domain of the groundwater model is indicated in red, the Veluwe area in black. (b) Elevation (m a.s.l.) of the Veluwe area. Veluwe area is indicated in black and locations of the time series with letters (A: 171154,445864; B: 187208,447643; C: 194583,453461$)$.

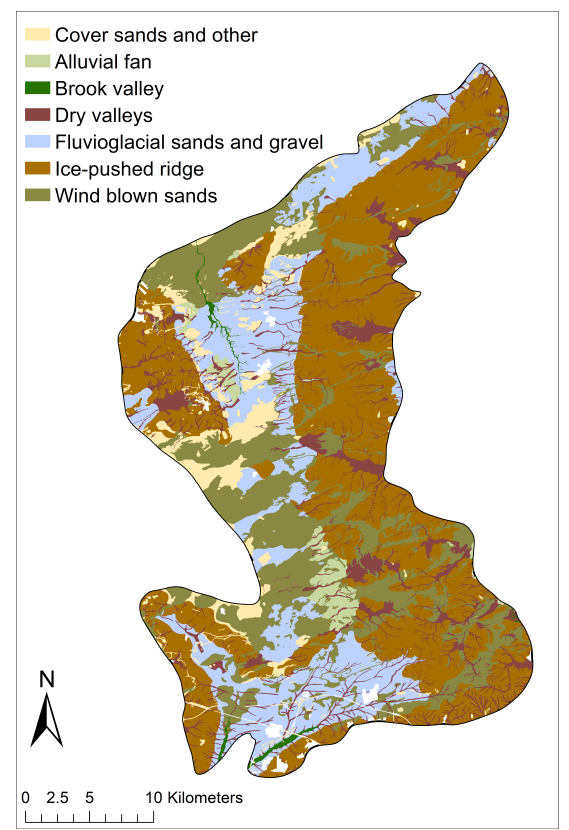

Figure 2. Main geomorphological features of the Veluwe based on Maas et al. [25]. 


\section{Materials and Methods}

\subsection{Groundwater Model}

Groundwater levels at the Veluwe were simulated with the regional model AZURE [27]. The regional model was chosen, because it includes the complex geomorphology of the area. The groundwater part of AZURE is based on MODFLOW [28] and it is coupled to MetaSWAP [29,30] for the simulation of the unsaturated zone. MetaSWAP simulates the actual evaporation and groundwater recharge based on meteorological conditions, soil properties and land use. Groundwater levels were simulated on a 250 by $250 \mathrm{~m}$ resolution on a daily basis for the Veluwe area and surroundings, in total an area of about $6500 \mathrm{~km}^{2}$ (Figure 1). To study the effect of land use changes on the groundwater levels, they were simulated with AZURE for the period 1986-2016 with land use of 1850 and 2008 with equal meteorological conditions.

\subsection{Data}

\subsubsection{Historical Conditions}

Land use of the Veluwe area was determined from historical maps and data for 1850, 1900, 1960 and 2008 (Figure 4). For 1850, a digital map for the province Gelderland "Gelderland Histland" is available with historical land use. There are no earlier maps known for The Netherlands, which are reliable enough (based on level of detail and drawn to scale) to allow for a comparison with current land use [31]. Information for 1900 and 1960 is available from Historical Landuse Netherlands maps [32]. The available 1900 map is based on hand drawn historical maps with a scale of 1:50,000, which are digitised and automatically classified [32]. For 1960, topographical maps are available with a scale of 1:25,000. The current land use (2008) is taken from a database with maps of National Land Use Netherlands. This map is based on satellite data from 2007 and 2008 [33]. Information from all these maps was simplified in this study to the following land use types: grass, agriculture and bare soil, heather, broad leaf forest, pine forest, urban area, drift sand, water and other. In this study, land use was fixed for 30 year periods, so the development of vegetation was not taken into account; instead land use change was estimated as jumps between the different periods.

Besides changes in land use, there were also changes in groundwater abstractions during the historical conditions. The groundwater of the Veluwe is important for the drinking water supply in this part of The Netherlands and abstractions started early in the 20th century [23]. The exact amount of abstracted groundwater was not known for the entire period. Therefore, estimated amounts of total abstractions across the Veluwe for 4 specific years were used as reference, respectively, 0, 21, 130 and $130 \mathrm{Mm}^{3}$ /year for 1895, 1930, 1995 and 2016. These reference numbers were interpolated linearly to create a time series for the entire period. To estimate the effect of the groundwater abstractions, the total was equally divided over the Veluwe area $\left(1250 \mathrm{~km}^{2}\right)$ and subtracted from the recharge.

Meteorological data (temperature and precipitation) were available from a nearby weather station from the Royal Netherlands Meteorological Institute (KNMI) from 1851 to 2016. Reference evaporation $\left(\mathrm{ET}_{r e f}\right)$ was derived from these data with Hargreaves and Allen [34] for the complete period. In the period 1957-2016, results from this method were calibrated with $\mathrm{ET}_{r e f}$ values calculated with Makkink [35], because radiation data were available from 1957 onward. Evaporation from interception was calculated with the Rutter interception model [36]. The soil evaporation and transpiration were estimated with a Hydrus-1D model [37]. The Hydrus model was used to simulate different combinations of soil type and land use to a depth of $5 \mathrm{~m}$ with a free draining boundary condition, so in a groundwater independent way. The combinations of land use and soil type were based on soil maps and the described historical information of land use. Rooting depth was different for each vegetation type, ranging from $0.3 \mathrm{~m}$ for grass 
to $3 \mathrm{~m}$ for broadleaf and pine forest. Total actual evaporation $\left(\mathrm{ET}_{a c t}\right)$ is defined as the sum of evaporated interception (results from the interception model), and soil evaporation and transpiration (results from Hydrus model).

The groundwater recharge was calculated for three different scenarios: (1) land use change and groundwater abstractions, (2) land use change only, (3) no land use change or abstractions. Groundwater recharge in the first scenario is defined as precipitation minus evaporation from actual land use and groundwater abstractions. In the second scenario, recharge is calculated as the difference between precipitation and evaporation from actual land use. In the last scenario, recharge is determined as the difference between precipitation and evaporation with constant land use of 1850 .

\subsubsection{Future}

To investigate the impact of climate change around 2050 (2036-2065) on the groundwater reservoir, climate scenarios specifically developed for The Netherlands by the KNMI [38] were used as input for the groundwater model. These climate scenarios are gridded datasets across The Netherlands [38]. The reference period for these scenarios is 1981-2010; input data for this period are based on observations and the existing climate change trend was removed. Four different climate scenarios are available, $G_{L}$, $\mathrm{G}_{H}, \mathrm{~W}_{L}$ and $\mathrm{W}_{H}$. The $\mathrm{G}$ scenarios ("moderate") represent a low global mean temperature increase, while the W scenarios ("warm") correspond with a stronger temperature increase. The subscripts $\mathrm{H}$ and $\mathrm{L}$ relate to regional changes in air circulation patterns. The model projections represent a strong response to climate forcing (subscript $\mathrm{H}$, "high value") with wetter winters and drier summers, and a relatively weak response (subscript L, "low value") with smaller changes in precipitation in both seasons. An overview of the changes in the most relevant meteorological variables in the four scenarios for the period 2036-2065, averaged over The Netherlands, is given in Table 1. For the Veluwe, all scenarios show an increase in winter precipitation, where the $\mathrm{W}_{H}$ and $\mathrm{G}_{H}$ scenarios show the largest increase (Figure 3a). In the summer months (June, July, August) the scenarios differ from each other. The $\mathrm{W}_{H}$ and $\mathrm{G}_{H}$ scenarios indicate a clear decrease in precipitation, whereas the $G_{L}$ scenario predicts a slight increase in precipitation. The $W_{L}$ scenario indicates an increase in June, precipitation similar to the reference period in July and a decrease in August. For $\mathrm{ET}_{r e f}$, all scenarios predict an increase in the period May-August (Figure 3b) with the $\mathrm{W}_{H}$ scenario predicting the largest increase. Changes in land use were not considered for this period.

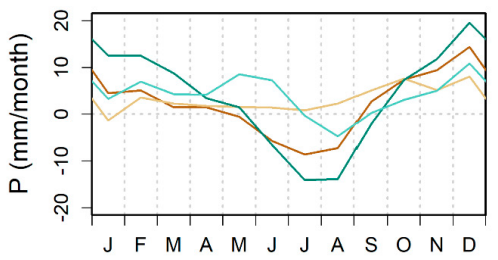

(a)

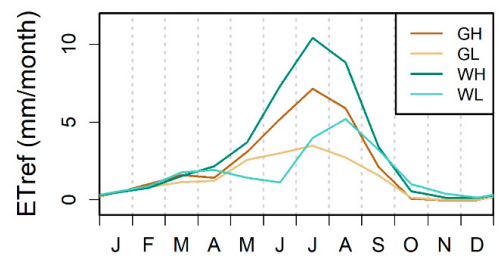

(b)

Figure 3. (a) Difference in monthly precipitation $(\mathrm{P}, \mathrm{mm})$ and $(\mathbf{b})$ reference evaporation $\left(\mathrm{ET}_{\text {ref }}, \mathrm{mm}\right)$ between the four scenarios and the reference period (1981-2010) averaged over 30 years for one representative grid cell at the centre of the Veluwe.

Table 1. Overview of the changes in the most relevant meteorological variables according to the climate change scenarios for the period 2036-2065 [38].

\begin{tabular}{ccccccc}
\hline Variable & Indicator & Climate (1981-2010) & GL & GH & WL & WH \\
\hline Temperature & Mean & $10.1{ }^{\circ} \mathrm{C}$ & $+1.0^{\circ} \mathrm{C}$ & $+1.4{ }^{\circ} \mathrm{C}$ & $+2.0{ }^{\circ} \mathrm{C}$ & $+2.3{ }^{\circ} \mathrm{C}$ \\
Precipitation & Mean amount & $851 \mathrm{~mm}$ & $+4 \%$ & $+2.5 \%$ & $+5.5 \%$ & $+5 \%$ \\
Solar radiation & Solar radiation & $354 \mathrm{~kJ} / \mathrm{cm}^{2}$ & $+0.6 \%$ & $+1.6 \%$ & $-0.8 \%$ & $+1.2 \%$ \\
\hline
\end{tabular}




\section{Results}

\subsection{Analysis Historical Period}

\subsubsection{Historical Conditions}

Considerable changes in land use occurred across the Veluwe between 1850 to 2008 (Figure 4). Heather decreased with $30 \%$ of the total area and drift sand with $26 \%$ of the total area. These land use types were replaced mainly with pine forest, which covered $44 \%$ of the total area in 2008 . Due to the increase in population in the second half of the 19th century, available land had to be used in more productive ways [39]. In that period and in the beginning of the 20th century, heather areas were transformed to agricultural land where possible, but mainly into pine forests [39]. Especially in the drier areas of the Veluwe, the planting of pine forest took place on a large scale early in the 20th century [39].
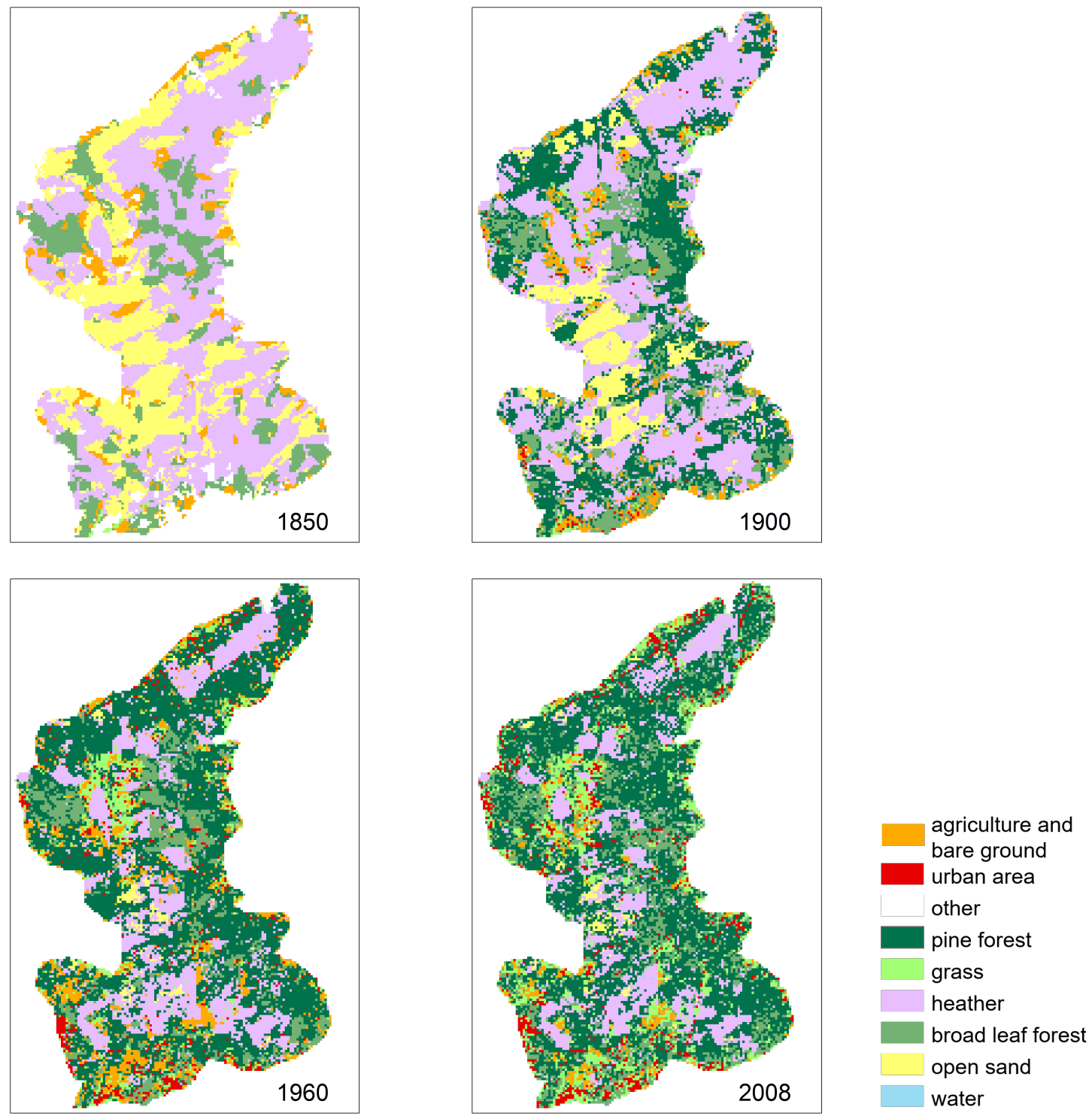

Figure 4. Historical land use across the Veluwe. 
Besides changes in land use, climate changed as well. Precipitation and temperature observations were available from a nearby weather station from KNMI. Both precipitation and temperature increased from 1851 to 2016 (Figure 5). Mean yearly precipitation in the period 1851-1880 was $697 \mathrm{~mm} /$ year and increased to $845 \mathrm{~mm} /$ year in the period 1987-2016. In the period 1851-1880 mean yearly temperature was $9.6^{\circ} \mathrm{C}$ and temperature increased to $10.3{ }^{\circ} \mathrm{C}$ in the period $1987-2016$.
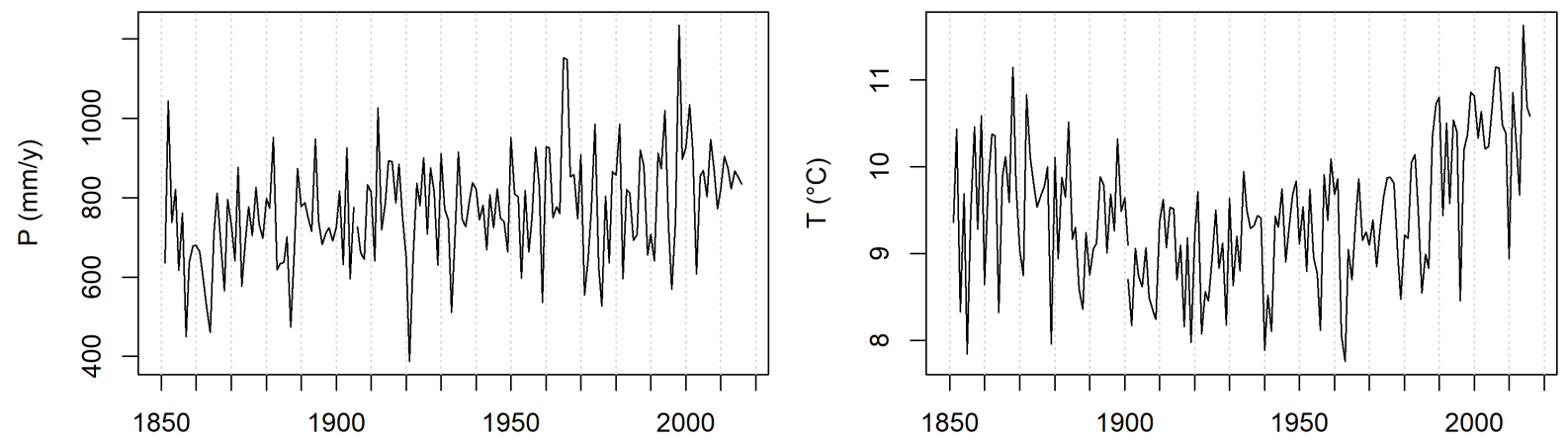

Figure 5. Yearly precipitation $(\mathrm{P})$ and mean yearly temperature (T) for 1851-2016 based on observations.

\subsubsection{Impact of Changes in Historical Period}

$\mathrm{ET}_{\text {act }}$ was simulated for the period 1850-2016 for a scenario with land use change and without land use change (Figure 6). During the whole period, $\mathrm{ET}_{a c t}$ increased when land use change was taken into account. In the period 1987-2016, mean yearly ET $_{a c t}$ for the entire Veluwe area was $153 \mathrm{~mm} /$ year (38.9\%) higher than mean yearly $\mathrm{ET}_{\text {act }}$ in the period 1851-1880, due to the combination of changes in land use and climate (Figure 6). When land use changes are not taken into account, by keeping land use of the year 1850 constant over the whole period, ET $_{a c t}$ increased with $35 \mathrm{~mm} /$ year $(9.4 \%)$ between 1851-1880 and 1987-2016 (Figure 6). The increase in $\mathrm{ET}_{\text {act }}$ over the historical period was thus mainly caused by land use changes. The increase in temperature and precipitation over time (Figure 5) had a small influence on the $\mathrm{ET}_{\text {act }}$. The change in pine forest over the Veluwe area in the historical period dominated the increase in $\mathrm{ET}_{a c t}$ (Figure 7). Heather and drift sand, with a lower $\mathrm{ET}_{\text {act }}$ compared to pine forest, decreased in area, hence total $\mathrm{ET}_{\text {act }}$ over the region increased.

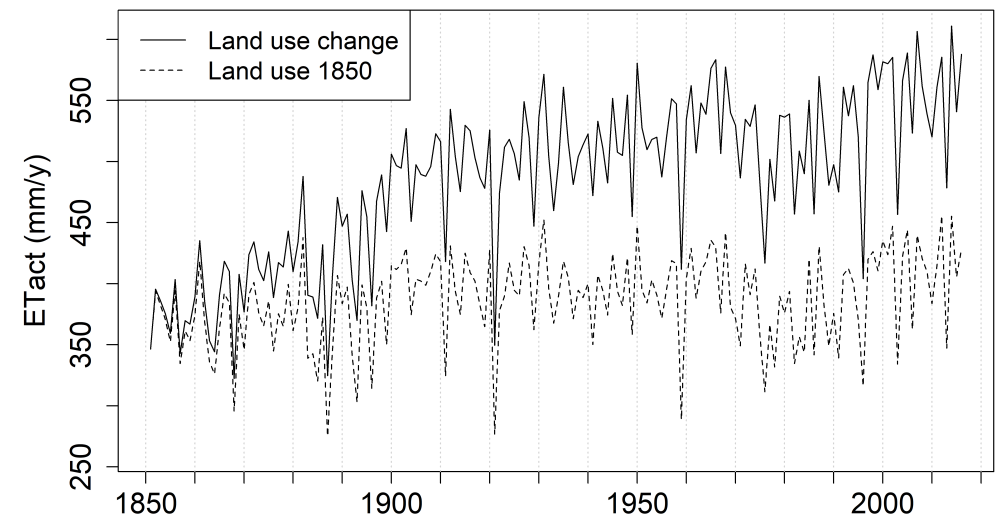

Figure 6. Mean yearly $\mathrm{ET}_{\text {act }}$ simulated with land use change and with a constant land use from 1850. 
Groundwater recharge was affected by these changes in $\mathrm{ET}_{\text {act }}$ (Figure 8) as well as by groundwater abstractions in the region. Recharge was determined for three different scenarios: (1) land use change and groundwater abstractions, (2) land use change only, (3) no land use change or abstractions. The results will be discussed in this order. During the historical period, the estimated yearly groundwater recharge decreased by $101 \mathrm{~mm} /$ year (33\%) for the scenario with actual land use, climate and groundwater abstractions between 1851-1880 and 1987-2016. When groundwater abstractions were excluded from the recharge estimate, the groundwater recharge decreased in the beginning of the 20th century with $37 \mathrm{~mm} /$ year (12\%) in 1911-1940 compared to 1851-1880. After this period, recharge estimates increased again until 1987-2016, during which estimated average yearly recharge was equal to the recharge in the historical period 1851-1880, namely $306 \mathrm{~mm}$ /year. The increase in precipitation over the whole period (148 mm/year) was almost equal to the increase in $\mathrm{ET}_{\text {act }}(153 \mathrm{~mm} /$ year $)$ due to changes in land use and climate. Without land use change, estimated groundwater recharge increased by $118 \mathrm{~mm} /$ year (36\%) between 1851-1880 and 1987-2016. The estimated groundwater recharge in scenario 3 (no land use change) in 1987-2016 was $142 \mathrm{~mm}$ /year higher than in scenario 2 (land use change only). When including the groundwater abstractions (scenario 1), estimated recharge decreased by $101 \mathrm{~mm}$ /year compared to scenario 2 (land use change only). Land use change, therefore, caused the largest decrease in groundwater recharge over the whole period. After the period of large pine plantations in the beginning of the 20th century, however, groundwater abstractions had a larger influence than land use change.

This decrease in groundwater recharge over time due to land use change and water abstractions led to lower groundwater levels over the whole region (Figure 9). If land use would have been constant from 1851 onward, current mean groundwater levels (based on a 30 year period) would be higher across the Veluwe. There are, however, large differences due to the presence of clay and loam layers in the ice-pushed ridges across the region (Figure 2). In the highest parts of the Veluwe, mean groundwater levels would have been more than $10 \mathrm{~m}$ higher with a maximum difference of $13.5 \mathrm{~m}$ (Figure 9). At the fringes of the Veluwe, on the other hand, only small increases are found and even a decrease up to $0.7 \mathrm{~m}$ in a valley in the northern region of the Veluwe (Figure 9). In these regions, vegetation apparently has sufficient water by capillary flow from the shallow groundwater table to evaporate at a potential rate.

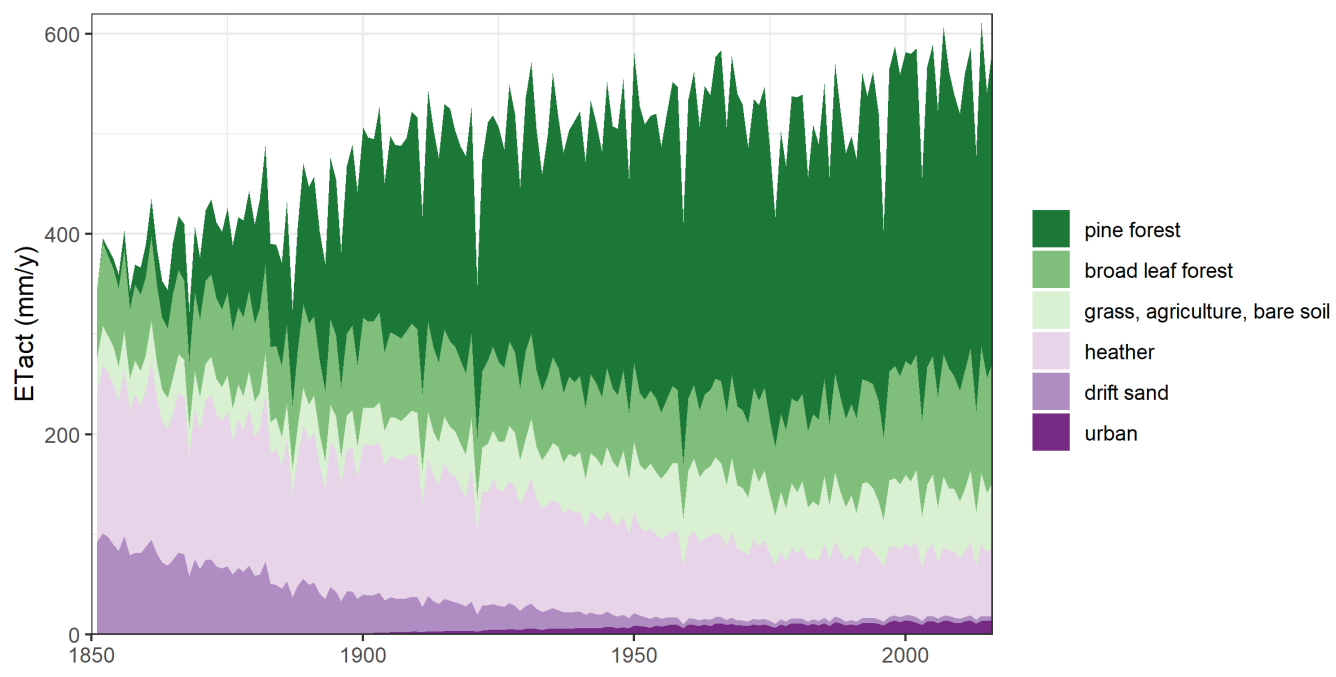

Figure 7. Mean yearly $\mathrm{ET}_{a c t}$ for the entire Veluwe area with the contribution of every land use type. 


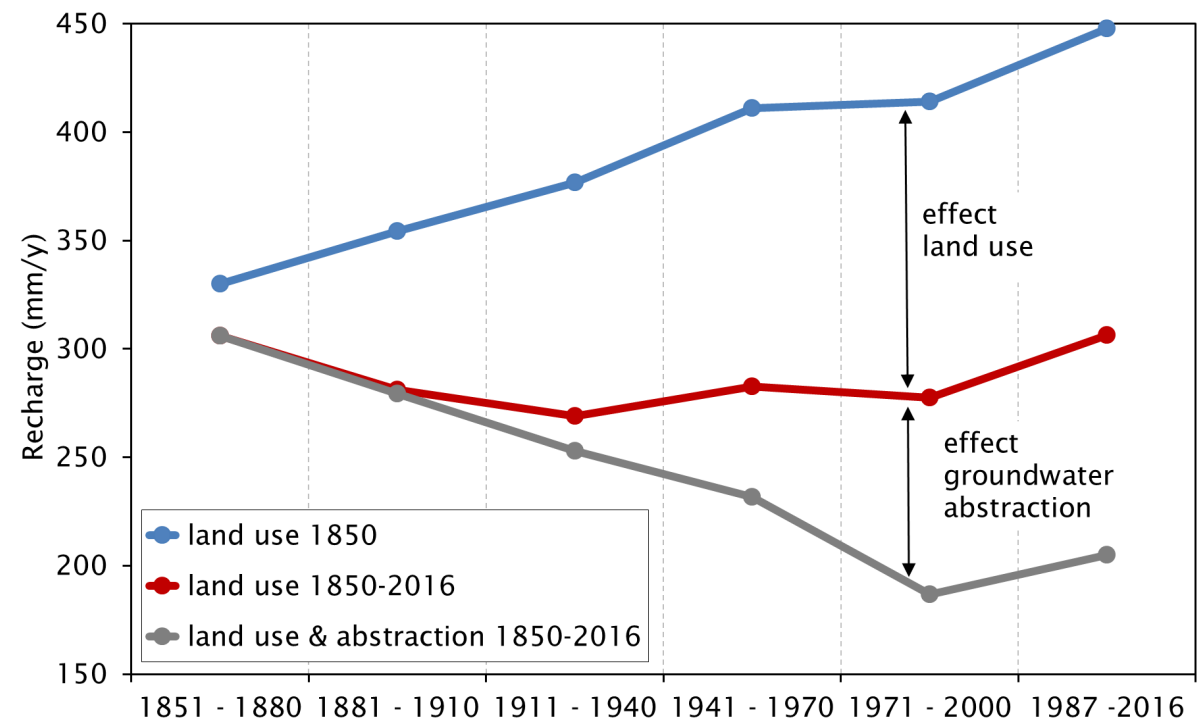

Figure 8. Groundwater recharge for the historical period based on three different scenarios: scenario with actual evaporation ( $\mathrm{ET}_{a c t}$ ) based on land use 1850, scenario with $\mathrm{ET}_{a c t}$ based on actual land use, scenario with $\mathrm{ET}_{a c t}$ with actual land use and including groundwater abstractions.

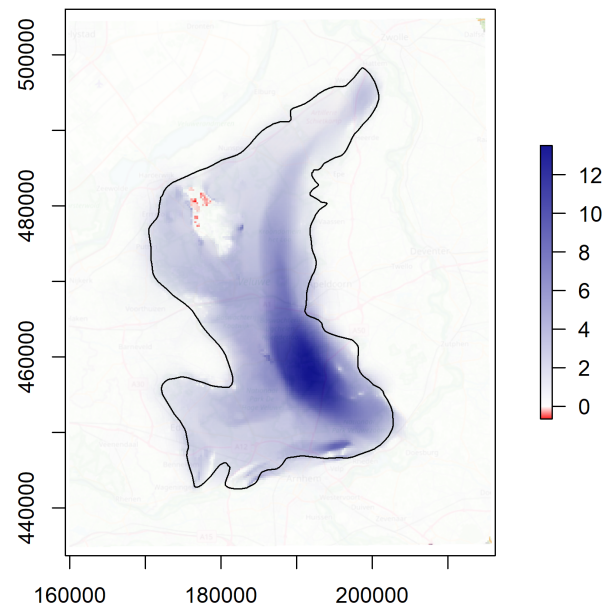

Figure 9. Difference in mean groundwater level $(\mathrm{m})$ between historical land use (1850) and current land use (2008) simulated over 1986-2016. The boundary of the Veluwe area is indicated in black.

\subsection{Analysis Future Period}

Groundwater levels were simulated for the period 2036-2065 with four different KNMI scenarios $\left(G_{L}, G_{H}, W_{L}\right.$ and $\left.W_{H}\right)$. The differences in simulated mean groundwater levels between the scenarios and the reference period over the whole Veluwe area are given in Figure 10. Across the Veluwe, all scenarios indicate an increase in the mean groundwater levels, with a maximum increase of $4.8 \mathrm{~m}$ for the $\mathrm{W}_{H}$ scenario. The eastern ice-pushed ridge of the Veluwe showed the largest increase in the mean groundwater head, whereas lower lying areas showed small changes.

The change in mean groundwater levels across the Veluwe can be explained by the importance of winter precipitation in this region in combination with the uncertainty in potential and actual evaporation. The increase in winter precipitation in all scenarios leads to more recharge and higher groundwater 
levels, because no extra water is lost through evaporation. When soil moisture is limited, the soil will not be able to deliver enough water to meet the higher potential evaporation demands of the vegetation. This phenomenon especially occurs in coarse textured sandy soils with a groundwater level deeper than approximately $2 \mathrm{~m}$ below root zone depth, so capillary flow from the groundwater level to the root zone is absent.

The amount of precipitation in winter is thus very important for the recharge of the groundwater reservoir. This is also illustrated by the difference in reaction between the $\mathrm{W}_{L}$ and $\mathrm{W}_{H}$ scenario. The total increase in precipitation for these scenarios is similar (Table 1), yet the maximum increase in groundwater levels for the $W_{L}$ scenarios is only $2.8 \mathrm{~m}$ versus $4.8 \mathrm{~m}$ in the $\mathrm{W}_{H}$ scenario. For the $\mathrm{W}_{L}$ scenario, precipitation increased more evenly over the year, not only in winter.
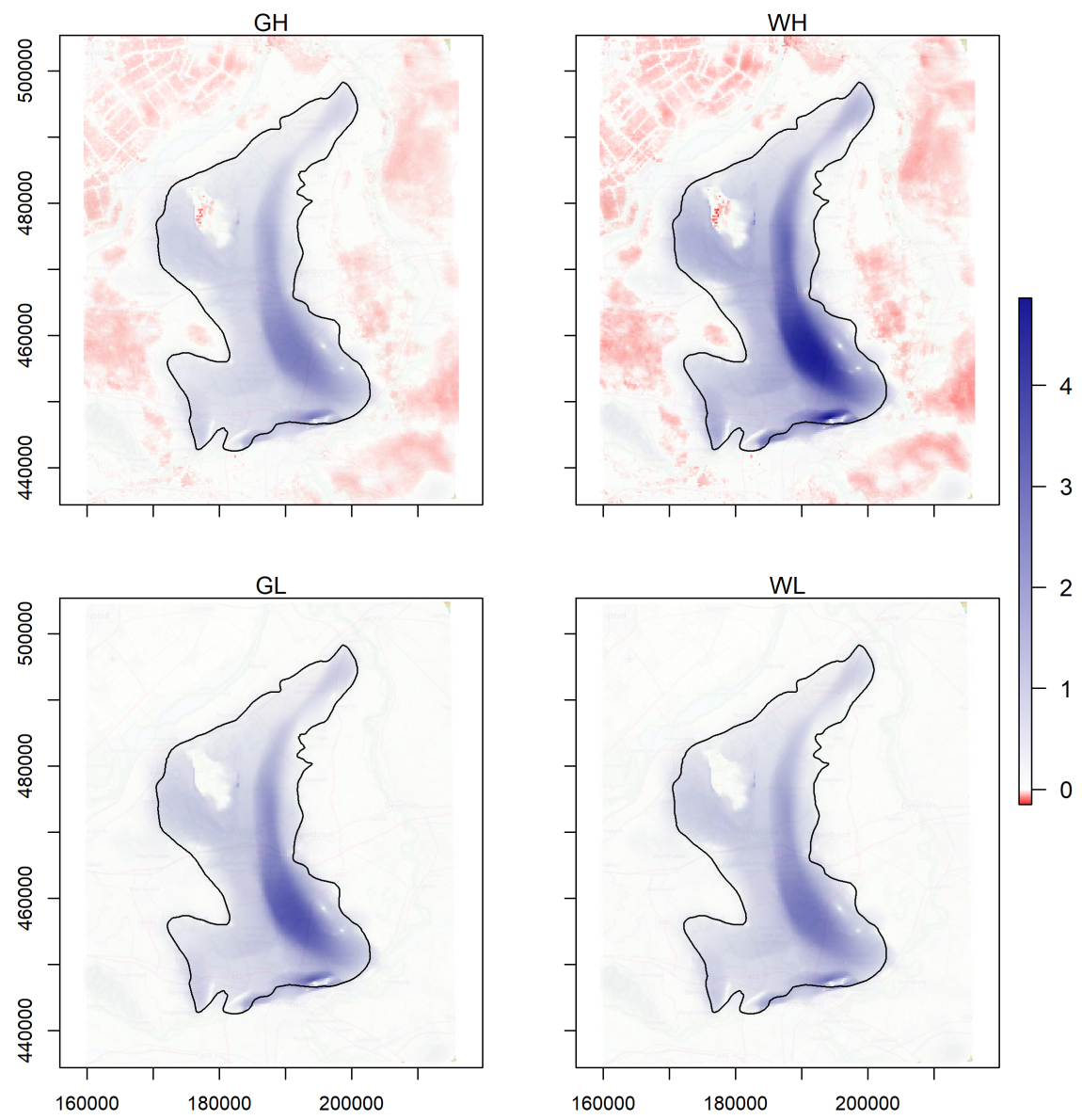

Figure 10. Changes in mean groundwater levels (m) between the climate change scenarios (2036-2065) and the reference period (1981-2010). The boundary of the Veluwe area is indicated in black.

The groundwater levels simulated with the $\mathrm{G}_{H}$ and $\mathrm{W}_{H}$ scenarios decreased in the surrounding agricultural areas of the Veluwe. In contrast to the elevated areas, these low-lying regions are thus prone to water shortages, especially in summer. These water shortages increase in the $G_{H}$ and $W_{H}$ scenarios (Figure 10). The different response to climate change of the low-lying regions is caused by the effect of shallow groundwater levels and the surface water levels in these regions. The shallow groundwater levels enable capillary supply of groundwater to the root zone in dry periods. On the other hand, the direct link to surface water levels leads to a fast response during periods with rain, because the extra water is directly 
discharged through the surface water. Differences in soil type (especially water holding capacity) also play an important role.

When focusing on changes over time (Figure 11) at selected locations across the southern part of the Veluwe (Figure 1), the different reaction to changes in climate between the Veluwe itself and the surrounding agricultural fields can be seen again. The elevated parts of the Veluwe show the slow response of the groundwater to interannual changes in recharge and climate change due to the large unsaturated zone and large drainage resistance in these regions (locations $B$ and $C$ ). The response in groundwater levels is completely different in the low-lying regions, where groundwater levels are linked to surface levels and phreatic levels react quickly to precipitation (location A). At this location, the difference between the scenarios is mainly found during the summer, when scenarios $G_{H}$ and $W_{H}$ can lead to water shortages and thereby to decreases in crop yields.

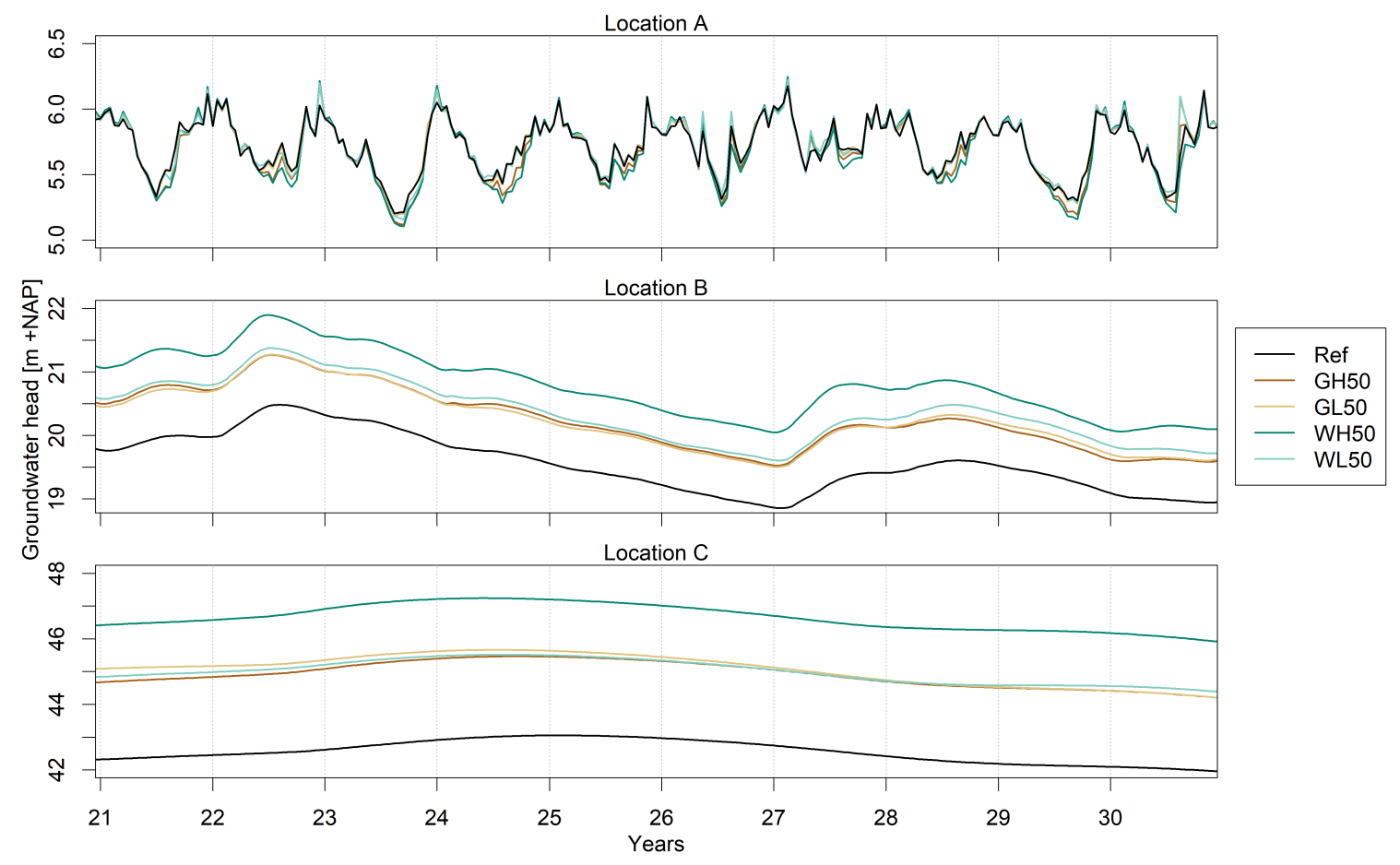

Figure 11. Time series of groundwater levels ( $\mathrm{m}$ a.s.l) at three selected locations across the southern part of the Veluwe for the last 10 years of the reference period and the climate scenarios.

\section{Discussion}

\subsection{Uncertainty Evaporation}

The impact of changes in land use depends mainly on the $\mathrm{ET}_{\text {act }}$ values of the different vegetation types. It is difficult to measure $\mathrm{ET}_{a c t}$, therefore, it is often estimated with a model. Here, Hydrus was used to estimate the $\mathrm{ET}_{\text {act }}$ values. The values for $\mathrm{ET}_{\text {act }}$ estimated with Hydrus for the different land use types corresponded well with values from literature. Average yearly actual evaporation for heather was slightly underestimated, with $361 \mathrm{~mm}$ /year compared to $430 \mathrm{~mm}$ /year in the literature [18], whereas evaporation from drift sands was overestimated by Hydrus with $380 \mathrm{~mm} /$ year compared to $201 \mathrm{~mm} /$ year in the literature [17]. Estimated actual evaporation for pine forest was equal to values in the literature with $622 \mathrm{~mm}$ /year compared to $630 \mathrm{~mm} /$ year [15]. The overestimation of evaporation from drift sands means 
change in groundwater recharge is underestimated, because the difference between evaporation from pine forest and drift sands is larger in reality than estimated in this study.

The changes in groundwater levels across the Veluwe area are simulated with AZURE and thus also influenced by the model choice. Recharge estimates depend on an accurate simulation of the $\mathrm{ET}_{a c t}$, especially in dry conditions. Groundwater levels were too low to provide vegetation with enough capillary flow to maintain high ET values; therefore, $\mathrm{ET}_{a c t}$ did not increase during the summer months. The response of forest to dry conditions, however, is still uncertain. The ability of forest to regulate stomatal opening and the large rooting depth lead to the conservative character and persistence of evapotranspiration of forests during heatwaves [40]. Especially the persistence of evapotranspiration during dry conditions might be underestimated by the model. In order to determine the influence of climate change on the vegetation across the Veluwe in more detail, it is very important to measure the $\mathrm{ET}_{\text {act }}$ for different vegetation types during dry conditions, such as during the summer of 2018.

\subsection{Scenarios for the Future}

This study focused on the impact of land use change in the historical analysis and on the impact of climate change in the analysis for the future. The KNMI scenarios only include the changes in climate, so changes in land use and water use were not taken into account for the future. In recent years, the pressure on groundwater resources has already increased in The Netherlands. During the 2018 drought, water usage increased, both for drinking water and irrigation in The Netherlands [41]. Since these drought events are expected to occur more often in the future [42], it can be assumed that water use will increase. This also affects the groundwater levels, and projected increases in these levels based on climate change only will be too positive. Extensive changes in land use across the Veluwe are not expected because the region is a nature area (Natura 2000). This means certain regions and habitats are protected and land use may not be changed. Conversions from pine forest to broadleaf forest, however, are possible. This research focused on the impact of climate change only and therefore excluded these developments. For a more realistic estimate of groundwater levels in the future, other scenarios could be used in further research. For The Netherlands, Delta scenarios were developed that include changes in land use and socio-economic changes [43]. These scenarios include a range in possible developments-for example, expecting either much more or less water availability challenges.

\subsection{Relation to Previous Studies}

Several previous studies have taken into account changes in land use or climate across the Veluwe. The impact of land use changes on the groundwater levels was investigated by Gehrels [22]. In this study, hypothetical scenarios were simulated in which all coniferous forests were replaced with deciduous forest for the Veluwe or where forests were only converted in a small area close to a groundwater abstraction site. In both cases, the conversion had a significant effect on groundwater levels. Gehrels [22] showed that the impact of conversion in the smaller area was of comparable magnitude to the nearby abstraction. Land use changes that occurred during the historical period had even higher impacts, because changes in recharge are larger for the conversion between heather/drift sands to coniferous forest than for conversions of forests only.

Evaluating the effect of converting part of the pine forest of the Veluwe to heather and drift sands was also done by Aus der Beek et al. [44]. Again a significant increase in groundwater levels was found in the region that was converted. The converted region was hypothetical to estimate possibilities to increase recharge in the future as part of the sustainable management of groundwater. In this study, the historical, actual changes to land use and their impacts have been shown. 
Climate change across the Veluwe was taken into account by Van Engelenburg et al. [23], who evaluate the scenario $G_{H}$. The changes in groundwater levels for this scenario from this study are similar to changes found by Van Engelenburg et al. [23]. They also indicated an increase in mean groundwater levels across the Veluwe. In this study, changes from all four climate scenarios were determined to include uncertainty in the predictions. The groundwater model in this study was updated since that in Van Engelenburg et al. [23] with a new parameterisation for heather [18]. Besides these differences, this study has shown the importance of land use changes compared to changes in climate and water abstractions.

\section{Conclusions}

The impacts of changes in land use and climate on a large strategic groundwater reservoir in The Netherlands, the Veluwe, were investigated for historical conditions (1851-2016) and future conditions (2036-2065). During the historical period, groundwater recharge and levels across the Veluwe decreased from 1850 onward. Over the whole period, land use change caused the largest decrease in groundwater recharge. In recent years, the groundwater abstraction contributed more to the decrease in groundwater recharge. Changes in climate would have resulted in higher groundwater recharge, but impacts of land use and abstractions were larger. Even though the impact of land use change depends on the actual evaporation, which is still not completely understood and depends on the chosen model, the change in recharge caused by the pine plantations was large enough to conclude that land use change had more impact than abstractions or climate for 1851-2016.

In future conditions, groundwater levels increased across the elevated parts of the Veluwe due to the predicted increase in winter precipitation. In the surrounding low-lying agricultural areas, drier conditions in summer led to lower groundwater levels in the $G_{H}$ and $W_{H}$ scenario. These regions could therefore be vulnerable to water shortages.

This study shows the importance of land use change compared to the effect of climate. The strategic groundwater reservoir of the Veluwe will be important in the future to alleviate drought impacts in surrounding areas. For sustainable management of the groundwater reservoir, land use change measures could be taken to increase the storage in the elevated parts and thereby mitigate the impact of climate change in low-lying regions even more.

Author Contributions: Conceptualization, M.H.J.V.H., B.R.V. and J.-P.M.W.; methodology, M.H.J.V.H., B.R.V., S.R. and J.-P.M.W.; software, S.R. and K.H.S.N.; formal analysis, M.H.J.V.H., B.R.V., S.R., K.H.S.N. and J.-P.M.W.; data curation, M.H.J.V.H., S.R. and K.H.S.N.; writing-original draft preparation, M.H.J.V.H.; writing-review and editing, M.H.J.V.H., B.R.V., S.R., K.H.S.N. and J.-P.M.W.; visualization, M.H.J.v.H and K.H.S.N. All authors have read and agreed to the published version of the manuscript.

Funding: This research was funded by Provincie Gelderland project Verdamping Veluwe: sturen en anticiperen and by the European Commission through the H2020 project BINGO (Grant Agreement Number 641739).

Conflicts of Interest: The authors declare no conflict of interest.

\section{Abbreviations}

$\mathrm{ET}_{\text {ref }} \quad$ reference evaporation

$\mathrm{ET}_{\text {act }}$ actual evaporation (sum of evaporated interception, soil evaporation and transpiration)

$\mathrm{G}_{L} \quad$ moderate climate scenario with weak response to changes in air circulation patterns

$\mathrm{G}_{H} \quad$ moderate climate scenario with strong response to changes in air circulation patterns

KNMI Royal Netherlands Meteorological Institute

$\mathrm{P} \quad$ precipitation

$\mathrm{W}_{L} \quad$ warm climate scenario with weak response to changes in air circulation patterns

$\mathrm{W}_{H} \quad$ warm climate scenario with strong response to changes in air circulation patterns 


\section{References}

1. Gosling, S.N.; Arnell, N.W. A global assessment of the impact of climate change on water scarcity. Clim. Chang. 2016, 134, 371-385. [CrossRef]

2. Schewe, J.; Heinke, J.; Gerten, D.; Haddeland, I.; Arnell, N.W.; Clark, D.B.; Dankers, R.; Eisner, S.; Fekete, B.M.; Colón-González, F.J.; et al. Multimodel assessment of water scarcity under climate change. Proc. Natl. Acad. Sci. USA 2014, 111, 3245-3250. [CrossRef] [PubMed]

3. Witte, J.P.M.; Runhaar, J.; Van Ek, R.; Van Der Hoek, D.C.J.; Bartholomeus, R.P.; Batelaan, O.; van Bodegom, P.M.; Wassen, M.J.; Van der Zee, S.E.A.T.M. An ecohydrological sketch of climate change impacts on water and natural ecosystems for The Netherlands: Bridging the gap between science and society. Hydrol. Earth Syst. Sci. 2012, 16, 3945-3957. [CrossRef]

4. Kummu, M.; Gerten, D.; Heinke, J.; Konzmann, M.; Varis, O. Climate-driven interannual variability of water scarcity in food production potential: A global analysis. Hydrol. Earth Syst. Sci. 2014, 18, 447-461. [CrossRef]

5. Van Vliet, M.T.H.; Yearsley, J.R.; Ludwig, F.; Vögele, S.; Lettenmaier, D.P.; Kabat, P. Vulnerability of US and European electricity supply to climate change. Nat. Clim. Chang. 2012, 2, 676-681. [CrossRef]

6. Delpla, I.; Jung, A.V.; Baures, E.; Clement, M.; Thomas, O. Impacts of climate change on surface water quality in relation to drinking water production. Environ. Int. 2009, 35, 1225-1233. [CrossRef]

7. Klein Tank, A.; Beersma, J.; Bessembinder, J.; Van den Hurk, B.; Lenderink, G. KNMI'14 Climate Scenarios for The Netherlands; Technical Report; KNMI: De Bilt, The Netherlands, 2014. Available online: http://projects.knmi. nl/publications/show Abstract.php?id=10756 (accessed on 5 October 2020).

8. Kløve, B.; Ala-Aho, P.; Bertrand, G.; Gurdak, J.J.; Kupfersberger, H.; Kværner, J.; Muotka, T.; Mykrä, H.; Preda, E.; Rossi, P.; et al. Climate change impacts on groundwater and dependent ecosystems. J. Hydrol. 2014, 518, $250-266$. [CrossRef]

9. Kundzewicz, Z.W.; Döll, P. Will groundwater ease freshwater stress under climate change? Hydrol. Sci. J. 2009, 54, 665-675. [CrossRef]

10. Green, T.R.; Taniguchi, M.; Kooi, H.; Gurdak, J.J.; Allen, D.M.; Hiscock, K.M.; Treidel, H.; Aureli, A. Beneath the surface of global change: Impacts of climate change on groundwater. J. Hydrol. 2011, 405, 532-560. [CrossRef]

11. Allen, A.; Chapman, D. Impacts of afforestation on groundwater resources and quality. Hydrogeol. J. 2001, 9, 390-400. [CrossRef]

12. Scanlon, B.R.; Reedy, R.C.; Stonestrom, D.A.; Prudic, D.E.; Dennehy, K.F. Impact of land use and land cover change on groundwater recharge and quality in the southwestern US. Glob. Chang. Biol. 2005, 11, 1577-1593. [CrossRef]

13. Dams, J.; Woldeamlak, S.T.; Batelaan, O. Predicting land-use change and its impact on the groundwater system of the Kleine Nete catchment, Belgium. Hydrol. Earth Syst. Sci. 2008, 12, 1369-1385. [CrossRef]

14. Bosmans, J.H.C.; van Beek, L.P.H.; Sutanudjaja, E.H.; Bierkens, M.F.P. Hydrological impacts of global land cover change and human water use. Hydrol. Earth Syst. Sci. 2017, 21, 5603-5626. [CrossRef]

15. Dolman, H.; Moors, E.; Elbers, J.; Snijders, W.; Hamaker, P. Het Waterverbruik Van Bossen in Nederland; Technical Report; Alterra: Wageningen, The Netherlands, 2000. Available online: http:/ / www.climatexchange.nl/projects / boshydrologie/Waterverbruik_Bossen.pdf (accessed on 5 October 2020).

16. Voortman, B.R.; Bartholomeus, R.P.; van der Zee, S.E.A.T.M.; Bierkens, M.F.P.; Witte, J.P.M. Quantifying energy and water fluxes in dry dune ecosystems of the Netherlands. Hydrol. Earth Syst. Sci. 2015, 19, 3787-3805. [CrossRef]

17. Stuyfzand, P.J. Hydrochemistry and Hydrology of the Coastal Dune Area of the Western Netherlands. Ph.D. Thesis, Vrije Universiteit Amsterdam, Amsterdam, The Netherlands, 1993.

18. Voortman, B.; van Huijgevoort, M.; Witte, J.P. Verdamping Van Natuurterreinen Berekend Met AZURE. De Parametrisatie Van Heide op Basis Van Lysimetermetingen en een Vergelijking Met Literatuurcijfers; Technical Report KWR2019.015; KWR: Nieuwegein, The Netherlands, 2019. 
19. Gleeson, T.; Alley, W.M.; Allen, D.M.; Sophocleous, M.A.; Zhou, Y.; Taniguchi, M.; VanderSteen, J. Towards Sustainable Groundwater Use: Setting Long-Term Goals, Backcasting, and Managing Adaptively. Groundwater 2012, 50, 19-26. [CrossRef]

20. Taylor, R.G.; Scanlon, B.; Döll, P.; Rodell, M.; van Beek, R.; Wada, Y.; Longuevergne, L.; Leblanc, M.; Famiglietti, J.S.; Edmunds, M.; et al. Ground water and climate change. Nat. Clim. Chang. 2013, 3, 322-329. [CrossRef]

21. Bierkens, M.F.P.; Wada, Y. Non-renewable groundwater use and groundwater depletion: A review. Environ. Res. Lett. 2019, 14, 063002. [CrossRef]

22. Gehrels, J.C. Groundwater Level Fluctuations; Separation of Natural from Anthropogenic Influences and Determination of Groundwater Recharge in the Veluwe Area. Ph.D. Thesis, Vrije Universiteit Amsterdam, Amsterdam, The Netherlands, 1999.

23. Van Engelenburg, J.; Hueting, R.; Rijpkema, S.; Teuling, A.J.; Uijlenhoet, R.; Ludwig, F. Impact of Changes in Groundwater Extractions and Climate Change on Groundwater-Dependent Ecosystems in a Complex Hydrogeological Setting. Water Resour. Manag. 2018, 32, 259-272. [CrossRef]

24. van Alphen, H.J.; Alves, E.; aus der Beek, T.; Bruggeman, A.; Camera, C.; Fohrmann, R.; Fortunato, A.; Freire, P.; Iacovides, A.; Iacovides, I.; et al. Characterization of the Catchments and the Water Systems; Technical Report, BINGO Deliverable 3.1; 2016. Available online: http:/ / www.projectbingo.eu/downloads/BINGO_Deliverable3.1_EC. pdf (accessed on 13 October 2020).

25. Maas, G.J.; van der Meij, W.M.; van Delft, S.P.J.; Heidema, A.H. Toelichting bij de Legenda Geomorfologische Kaart Van Nederland 1:50,000 (2019); Wageningen Environmental Research: Wageningen, The Netherlands, 2019.

26. Nijhuis, K. Historisch Landgebruik Van de Veluwe in Hydrologisch Perspectief. Master's Thesis, Wageningen University: Wageningen, The Netherlands, 2017.

27. De Lange, W.; Borren, W. Grondwatermodel AZURE versie 1.0. Actueel Instrumentarium voor de Zuiderzee Regio; Technical Report; Deltares: Delft, The Netherlands, 2014.

28. Harbaugh, A.W. MODFLOW-2005, the U.S. Geological Survey Modular Ground-Water Model-The Ground-Water Flow Process; Technical Report; USGS. 2005. Available online: https://pubs.er.usgs.gov/publication/tm6A16 (accessed on 13 October 2020).

29. van Walsum, P.E.V.; Groenendijk, P. Quasi steady-state simulation of the unsaturated zone in groundwater modeling of lowland regions. Vadose Zone J. 2008, 7, 769-781. [CrossRef]

30. van Walsum, P.E.V.; Veldhuizen, A.A.; Groenendijk, P. SIMGRO 7.2.0, Theory and Model Implementation; Technical Report; Alterra: Wageningen, The Netherlands, 2011. Available online: http://nhi.nu/nl/files/8814/2662/2842/ Handleiding_SIMGRO_7.2.0_Engels_Report_913_1_V7_2_0.pdf (accessed on 13 October 2020).

31. Koeman, C. Geschiedenis Van de Kartografie Van Nederland: Zes Eeuwen Land-en Zeekarten en Stadsplattegronden; Canaletto: Alphen aan den Rijn, The Netherlands, 1983.

32. Knol, W.C.; Kramer, H.; Gijsbertse, H. Historisch Grondgebruik Nederland; een Landelijke Reconstructie van het Grondgebruik Rond 1900; Alterra-Rapport 573; Alterra: Wageningen, The Netherlands, 2004. Available online: https: / / www.wur.nl/nl/Publicatie-details.htm?publicationId=publication-way-333238323739 (accessed on 13 October 2020).

33. Hazeu, G.W.; Schuiling, C.; Dorland, G.J.; Oldengarm, J.; Gijsbertse, H.A. Landelijk Grondgebruiksbestand Nederland versie 6 (LGN6); Vervaardiging, Nauwkeurigheid en Gebruik; Alterra-Rapport 2012; Alterra: Wageningen, The Netherlands, 2010. Available online: https://www.wur.nl/nl/Publicatie-details.htm?publicationId= publication-way-333931373630 (accessed on 13 October 2020).

34. Hargreaves, G.H.; Allen, R.G. History and evaluation of Hargreaves evapotranspiration equation. J. Irrig. Drain. Eng. 2003, 129, 53-63. [CrossRef]

35. Makkink, G.F. Testing the Penman formula by means of lysimeters. J. Inst. Water Eng. 1957, 11, $277-288$.

36. Rutter, A.; Kershaw, K.; Robins, P.; Morton, A. A predictive model of rainfall interception in forests, 1 . Derivation of the model from observations in a plantation of Corsican pine. Agric. Meteorol. 1971, 9, 367-384. [CrossRef] 
37. Šimůnek, J.; Šejna, M.; Saito, H.; Sakai, M.; Van Genuchten, M.T. The HYDRUS-1D Software Package for Simulating the Movement of Water, Heat, and Multiple Solutes in Variably Saturated Media, Version 4.08; HYDRUS Software Series 3; Technical Report; Department of Environmental Sciences, University of California Riverside: Riverside, CA, USA, 2008.

38. KNMI. KNMI'14: Climate Change Scenarios for the 21st Century-A Netherlands Perspective; Technical Report; KNMI: De Bilt, The Netherlands, 2014.

39. Neefjes, J. Landschapsbiografie Van de Veluwe: Historisch-Landschappelijke Karakteristieken en hun Ontstaan; Rijksdienst voor het Cultureel Erfgoed and Staatsbosbeheer, Amersfoort, The Netherlands, 2018. Available online: https: / /library.wur.nl/WebQuery/groenekennis/2284674 (accessed on 13 October 2020).

40. Teuling, A.J.; Seneviratne, S.I.; Stöckli, R.; Reichstein, M.; Moors, E.; Ciais, P.; Luyssaert, S.; van den Hurk, B.; Ammann, C.; Bernhofer, C.; et al. Contrasting response of European forest and grassland energy exchange to heatwaves. Nat. Geosci. 2010, 3, 722-727. [CrossRef]

41. van den Eertwegh, G.; Bartholomeus, R.; de Louw, P.; Witte, F.; van Dam, J.; van Deijl, D.; Hoefsloot, P.; Clevers, S.; Hendriks, D.; van Huijgevoort, M.; et al. Droogte in Zandgebieden Van Zuid-, Midden-en Oost-Nederland: Rapportage Fase 1: Ontwikkeling Van Uniforme Werkwijze Voor Analyse Van Droogte en Tussentijdse Bevindingen; Technical Report; 2019. Available online: https:/ / edepot.wur.nl/511196 (accessed on 13 October 2020).

42. Philip, S.Y.; Kew, S.F.; van der Wiel, K.; Wanders, N.; van Oldenborgh, G.J. Regional differentiation in climate change induced drought trends in The Netherlands. Environ. Res. Lett. 2020. [CrossRef]

43. Wolters, H.A.; van den Born, G.J.; Dammers, E.; Reinhard, S. Deltascenario's Voor de 21e Eeuw, Actualisering 2017; Technical Report; Deltares: Utrecht, The Netherlands, 2018. Available online: https: / / media.deltares.nl/ deltascenarios/Deltascenarios_actualisering2017_hoofdrapport.pdf (accessed on 13 October 2020)

44. Aus der Beek, T.; Alves, E.; Becker, R.; Bruggeman, A.; Fortunato, A.B.; Freire, P.; Gragne, A.; van Huijgevoort, M.H.J.; Iacovides, A.; Iacovides, I.; et al. D3.4 Model Results for Water and Land Use Scenarios Completed and Analysed. Technical Report, BINGO Deliverable 3.4. 2018. Available online: http:/ / www.projectbingo.eu/content/deliverables (accessed on 13 October 2020).

Publisher's Note: MDPI stays neutral with regard to jurisdictional claims in published maps and institutional affiliations.

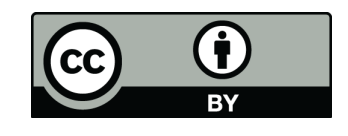

(C) 2020 by the authors. Licensee MDPI, Basel, Switzerland. This article is an open access article distributed under the terms and conditions of the Creative Commons Attribution (CC BY) license (http:/ / creativecommons.org/licenses/by/4.0/). 